\title{
Should We Presume State Protection?
}

\author{
JAMES C. HATHAWAY AND AUDREY MACKLIN
}

\section{Abstract}

Professors Hathaway and Macklin debate the legality of the "presumption of state protection" that the Supreme Court of Canada established as a matter of Canadian refugee law in the Ward decision. Professor Hathaway argues that this presumption should be rejected because it lacks a sound empirical basis and because it conflicts with the relatively low evidentiary threshold set by the Refugee Convention's "well-founded fear" standard. Professor Macklin contends that the Ward presumption does not in and of itself impose an unduly onerous burden on claimants, and that much of the damage wrought by the presumption comes instead from misinterpretation and misapplication of the Supreme Court's dictum by lower courts.

\section{Résumé}

Les professeurs Hathaway et Macklin reconsidèrent la légalité de la "présomption de la protection de l'État» que La Cour suprême du Canada avait promulgé comme principe de droit canadien en matière de réfugiés dans le jugement Ward. Le professeur Hathaway soutient que cette présomption devrait être rejetée en raison de son manque de fondement empirique rigoureux ainsi que de son incompatibilité avec le niveau de preuve relativement faible impliqué par la norme de «crainte justifiée» établie par la Convention relative au statut des réfugiés. La professeure Macklin estime que la présomption Ward n'impose guère en soi un fardeau excessivement lourd sur les demandeurs, et que la plupart des problèmes engendrés par la présomption découlent des erreurs d'interprétation ou d'application de la décision de la Cour suprême de la part des tribunaux inférieurs.
$\mathrm{M}$ ore than two decades later, the Supreme Court of Canada's decision in Ward v Canada, [1993] 2 SCR 689 remains one of the world's most significant refugee law decisions. Ward's holdings on such matters as the meaning of both "membership of a particular social group" and the relevance of non-state agents of persecution were groundbreaking and of indisputable value to the evolution of refugee protection in Canada and around the world. Indeed, Ward made clear the overarching purpose of refugee law, which informs nearly every interpretive question: "International refugee law was formulated to serve as a back-up to protection one expects from the state of which an individual is a national. It was meant to come in to play only in situations when that protection is unavailable, and then only in certain situations. The international community intended that persecuted individuals be required to approach their home state for protection before the responsibility of other states becomes engaged."

More controversially, however, the Court addressed the question of how best to operationalize the surrogate protection principle. While in Ward the home country had conceded its inability to protect, the Court nonetheless opined about how to proceed in the more usual case where there is no such concession: "Clear and convincing confirmation of a state's inability to protect must be provided. For example, a claimant might advance testimony of similarly situated individuals let down by the state protection arrangement or the claimant's testimony of past personal incidents in which state protection did not materialize. Absent some evidence, the claim should fail, as nations should be presumed capable of protecting their citizens. Security of nationals is, after all, the essence of sovereignty. Absent a situation of complete breakdown of state apparatus ..., it should be assumed that the state is capable of protecting a claimant" (emphasis added).

While clearly obiter dicta, this passage has generated real controversy. First, courts have struggled with the question of whether the adequacy of state protection focuses on the 
efforts made by the state to protect, or on whether state action is effective in reducing the risk of persecution below the threshold of "reasonable chance." Second and more generally, the basic notion of a "presumption" of state protection has led lower courts to impose a significant burden on persons seeking recognition of refugee status. For example, the Federal Court of Appeal in Carrillo v Canada, 2008 FCA 94, at [30], interpreted Ward as imposing on refugee claimants a burden to "adduce relevant, reliable and convincing evidence which satisfies the trier of fact on the balance of probabilities that the state protection is inadequate."

In The Law of Refugee Status ${ }^{1}$ James Hathaway and Michelle Foster argue that the notion that states are "presumed to protect" their citizens, as suggested in Canada $v$ Ward, [1993] 2 SCR 689, is unsound. In their view the resultant duty on refugee claimants to rebut a presumption of state protection is at odds with the duty of the applicant to show no more than a "well-founded fear" of being persecuted. More generally, Hathaway and Foster endorse the view of the Full Federal Court of Australia in A. v Minister for Immigration and Multicultural Affairs, (1993) 53 ALD 545, at [41] that the Ward presumption should be rejected on the grounds that there is no basis in principle for importing a presumption that lacks a solid empirical foundation. They contend that the question of whether a state is unable or unwilling to provide protection is a simple question of fact that must, like all questions of fact, be investigated in line with the shared duty of fact-finding. In contrast, Audrey Macklin contends that, properly interpreted, the presumption of state protection as articulated by the Supreme Court of Canada in Ward does not require refugee claimants fearing persecution by nonstate actors to rebut a presumption of state protection on a balance of probabilities. Rather, the Federal Court of Appeal has misconstrued and misapplied the Supreme Court's dictum on the presumption of state protection.

We reproduce here a recent exchange between Hathaway and Macklin on the significance and ramifications of the notion of a presumption that states can and will protect their citizens.

\section{Audrey Macklin to James Hathaway, 25 June 2014}

1. I disagree with you that the Supreme Court of Canada in Ward made a critical mistake in talking about a presumption that states are able to protect their nationals, which it derived as an implication flowing from state sovereignty. Contra the Australian Full Federal Court in $A$, not all presumptions require a basic fact. Most notably, criminal law presumes sanity without any underlying basic fact. The presumption of innocence is another, albeit more complicated example. So even if it is a presumption without a basic fact, that is not fatal.
2. But more importantly, I think that we do presume that states are able and willing to protect their citizens (which they do by refraining from persecuting them and by protecting them from abuses by others). That presumption explains why the burden is on a refugee claimant to make out (on a standard of reasonable chance/serious risk) the elements of his/her claim (well-founded fear of persecution on enumerated grounds). It is true that the court didn't have to say anything about it and I am persuaded by your critique (not to mention subsequent Federal Court jurisprudence) that it definitely would have been better not to have said anything. Read in its best light, however, the Supreme Court in Ward is saying no more than "It is the job of a state to protect its citizens. It's up to you, refugee claimant, to prove that your state won't do its job with respect to you." I think that the mistake in the Federal Court jurisprudence is to double up on that burden by adding a separate (and tougher) burden specific to failure of state protection qua discrete element in the refugee analysis.

\section{James Hathaway to Audrey Macklin, 28 June 2014}

I'm intrigued by your point about whether a presumption needs a factual basis or not. Let me push you a bit on this one.

1. The presumption of state protection is actually a factual presumption-and in this sense I think it is quite different from the presumption of innocence, which is really just a means of operationalizing the criminal law's burden of proof. If, as I think must be the case, entitlement to refugee status ought to be an open-ended inquiry into the merits of the factual need for surrogate protection, it seems to me that the bar for a "factual presumption" would have to be set quite high-something that is usually, perhaps nearly always, the case. If that is not so, I can see no reason to encumber the refugee with the duty to dislodge the presumption rather than simply asking the question.

2. This does not mean, by the way, that I'm not persuaded by Ward's true presumption-in favour of a well-founded fear of being persecuted if an absence of state protection is shown. I think the empirical case is definitely stronger for this than the "states can and will protect" presumption, but not so overwhelmingly clear that the question shouldn't just be asked. So while we agree that the "double burden of proof" is the most patent manifestation of the problem, it seems to me to flow from the counterfactual factual presumption.

Thoughts? 


\section{Audrey Macklin to James Hathaway, 29 June 2014}

Glad to be pushed on this. The way you framed your response helps me see more clearly where and why we differ in our route to the same outcome.

1. I think the presumption of state protection (POSP) is, like the presumption of innocence (POI), a legal and not a factual presumption. Perhaps the Federal Court's mistake can be rephrased as erroneously treating the presumption of state protection as if it were a factual presumption. I assume that we agree that the presumption of innocence is a legal (and not factual) presumption-after all, about $2 / 3$ of people who are charged are convicted. So as factual presumptions go, it doesn't work. I also agree that the main point of the POI is to allocate the burden of proof: it is the state that must prove that the person committed the offence, and not the individual who must prove her innocence. There are various sound reasons for allocating the burden that way. And the burden is heavy (beyond a reasonable doubt), but for reasons that have little to do with the factual likelihood that the accused committed the offence.

2. Similarly, I think the POSP is a legal presumption that allocates the burden of proof to the claimant to establish the elements of the refugee claim. We express/justify it by saying something like this: The international state system is predicated on the claim that states are able and willing to protect their citizens. That is part of the justification for the allocation of sovereignty to individual states, etc. And that is also why refugee protection is (as you put it) surrogate protectionmeant to address the anomalous situation where the state doesn't actually fulfil its obligations. If it wasn't a departure from the "norm" of state protection, we wouldn't call it surrogate. So we put the burden on the one who challenges the norm to show that expected protection will not be forthcoming in his case.

3. To the extent that Posp is a legal and not a factual presumption, it doesn't tell us anything about how "heavy" the burden on the claimant ought to be to make her case. And, for a variety of good reasons, courts have decided that the standard should be relatively light"reasonable chance" or "serious reasons," rather than balance of probabilities or beyond a reasonable doubt.

4. So we say that the states are presumed able/willing to protect their citizens (because the international state is predicated on it, legal fiction though it may be). That means that the burden is on the claimant to make out the elements of a refugee claim (well-founded fear of persecution on an enumerated ground), according to the standard of proof (reasonable chance) that we think appropriate. The presumption is not factual, and so tells us nothing about how hard it will be to dislodge it as an empirical matter in any given case. And if the burden is relatively light (in comparison to the criminal or civil standard), this is the product of many factors. One might be the factual weakness of the legal presumption, but I'm not sure about thatI'd have to think about it more deeply.

5. Now, there is another way of coming at this, which you hint at in talking about an "open-ended inquiry." One could imagine a system that did not allocate the burden of proof. It would be a purely inquisitorial system in which the decision-maker was responsible for investigating and determining refugee status. In such a system, there would be no need for a legal presumption, because there is no burden to allocate as between parties. But that is not the system we have-even when interpreted generously to allow for the engaged, inquisitorial decision-maker and a non-adversarial process. I am not commenting on the desirability of such a process, just on whether it exists at present. But more significantly, it is not the system that the Supreme Court thought we had when it decided Ward. It operated on the understanding that one party did bear the burden, and that party was the claimant. The presumption of state protection, like the presumption of innocence, is a device for allocating the burden at the outset. It is not pulled out of thin air, but it should not be misconstrued as a factual presumption that applies to a specific element of the refugee test (existence of persecution).

6. So, if I thought the presumption was a factual one, I think I would agree with you. But I don't think it is. And I think that when the Supreme Court talks about clear and convincing evidence, etc., it is only imposing an evidentiary burden on the claimant, as in "If you are from a country where the state apparatus has not broken down (however defined) and you don't show clear and convincing evidence re: lack of state protection, you are at risk of a negative inference being drawn." We could have done without it, in my view, but I don't think it is as damaging as the Federal Court has made it through its own distortions.

So, if I've understood you correctly, our divergence stems from a difference of opinion about whether the POSP is best understood as a legal or a factual presumption. Does that seem right?

James Hathaway to Audrey Macklin, 30 June 2014

1. I think your para. 2 is the nub of the issue. The presumption of innocence in criminal law serves a helpful 
function in reinforcing in a practical way the agreed legal standard of proof-i.e., proof beyond a reasonable doubt.

2. As your analysis in para. 2 makes very clear, the PosP invented by Canadian courts does exactly the opposite: it undermines the legal standard of proof-wellfounded fear, i.e., only a reasonable chance or serious possibility-by requiring more of the claimant than the Refugee Convention allows. Thus, when you say (accurately) that "the POsP is a legal presumption that allocates the burden of proof to the claimant to establish the elements of the refugee claim," you are right-that's exactly what it does, and at a high level. But that is also precisely why it is untenable as a matter of international law, since there is a shared duty of fact-finding that requires only that at the end of the day the evidence adduced meets the well-founded fear test. My guess is that this is why other countries don't go down this road (even if they invent equally awful mechanisms to avoid their responsibilities).

3. So this brings me back to where I began: if this is being treated as a "legal" presumption, it shouldn't be-that standard is well-founded fear. Hence it would only be appropriate to have a POSP if it were a "factual" presumption-which it can't be, for the reasons we agree on.

Are we getting closer?

\section{Audrey Macklin to James Hathaway, 30 June 2014}

1. Almost there, I think. I think, however, that you conflate two separate questions: (a) who has the burden of proof?; and (b) what is required to discharge that burden?

2. The first is the legal burden of proof and it is allocated to the state in criminal law, and the plaintiff in civil cases. The second is the standard of proof and could, in principle, be answered in different ways-beyond a reasonable doubt, on a balance of probabilities, whatever. After all, we allocate the burden of proof to the plaintiff in civil cases, but the standard is only balance of probabilities; in criminal law, we allocate the burden to the state, and the standard is higher. But if the state is suing someone in civil court for a tort action, the standard is balance of probabilities. So, knowing where the legal burden lies does not answer what the standard of proof is. What we have in refugee law (on the best reading of Ward) is a legal burden on the claimant, on a standard of proof that is "reasonable chance" or "serious possibility."

3. I'm not sure if we are struggling with semantic murkiness, but my sense is that you want to endorse what I described in paragraph 5 in my previous email: there can be no legal burden of proof in a refugee claim. The decision-maker is conducting an inquiry more than an adjudication, and so the concept of burden of proof is simply inapposite.

So I think this is where we come down so far:

1. We agree that the Posp purports to be a legal burden of proof. I think it's legally permissible (and inevitable in practice, but that's another story) to put a legal burden on the claimant. You do not.

2. I think that the Posp puts the legal burden on a claimant to make out a well-founded fear of being persecuted on a standard of proof of reasonable chance or serious possibility. You think that once the legal burden is on the claimant, a higher standard of proof necessarily follows, which cannot be reconciled with "reasonable chance" or "serious possibility." I think that is mistaken, and this mistake gives rise to the incoherent approach (not yours, the Federal Court's) of asking whether a claimant has shown on a balance of probabilities that there is a reasonable chance of persecution.

3. You think that if Posp cannot lawfully operate as a legal presumption, it must be a factual presumption. Factual presumptions are valid in principle, depending on the rationality of the inference from basic fact to presumed fact. But Posp fails as a factual presumption. If I accepted that pospis a factual presumption, I would agree with you that it fails.

4. I also think that even if it was accepted as a factual presumption, it could lawfully require no more of a claimant than that she point to evidence that, if accepted, could show that the level of state protection still left a reasonable chance of persecution in her case. That is how an evidentiary burden works and I think this is what Ward says (on its best reading). Not sure where you are on this point.

5. To add to your real world skepticism about what other countries do/don't do, it is perhaps noteworthy that Maldonado, [1980] 2 FC 302 says that sworn evidence is presumed true. So, if taken seriously, that would go a long way to alleviating the concern that a legal burden on a claimant is unduly onerous, since sworn testimony is the main evidence in any case. Of course, Maldonado is honoured in the breach, just as other countries without a legal burden of proof on claimants find ways to reject claims anyway.

I really think our disagreement is about whether it is permissible to put a legal burden of proof on a claimant, and whether that necessarily dictates what I call the standard of proof. You say no/yes and I say yes/no. I'm drawing on 
my understanding of how burdens work in criminal law (although I've not taught it in a long time).

I should say that I quite enjoy trying to work out this point, and I also suspect that we are the only people in the world who would find it interesting.

\section{James Hathaway to Audrey Macklin, 30 June 2014}

1. If by "legal burden of proof" you mean who has the burden of production, then by and large-though subject to the shared duty of fact-finding!-I can agree that this lies with the person seeking recognition of status. But a legal burden of proof should not in my view be given any greater substantive role than this, since there is ultimately only one evidentiary question in refugee status assessment and that is defined by the "well-founded fear" standard-nothing more, nothing less.

2. Assuming we're now both speaking about the quantitative question (how much evidence is enough?), then I think that a "presumption" of state protection means that the applicant can in practice only succeed by showing more than the well-founded fear standard requires. For example, in Cardoza Fonseca, (1987) 480 Us 421, the Us Supreme Court rejected the view that anything approaching balance of probabilities was required. Yet how do you overcome a presumption with only evidence of a $10 \%$ risk? Any reference to having to show anything on a balance of probabilities, much less to rebut a presumption, seems almost inevitably to drive us to something beyond that standard (a concern that seems clearly borne out in the Canadian Federal Court caselaw).

3. We agree that factual presumptions are valid in principle, depending on the rationality of the inference from basic fact to presumed fact and that POSP fails as a factual presumption. To me the Supreme Court's test is clearly an (unwarranted) factual presumption.

4. I agree that a reading of Ward along the lines of what you posit would help to alleviate the problem-but this does not seem remotely what the Federal Court understands it to mean. And perhaps I have a bit more sympathy for the unhappy approach of the lower courts and tribunals because I think that the Supreme Court of Canada unnecessarily complicated things by referencing a presumption when simply leaving it as a neutral question of fact would have been better.

I'm wondering if our difference comes from the fact that you say that you're approaching this from a criminal law point of view, whereas I am not. I don't really understand why you would want to anchor your thinking in such a different body of law, given the quite explicit rejection of traditional evidentiary standards (criminal or civil) by the decision to adopt the "well-founded fear" standard-sui generis to refugee law. Is this at the root of our contrasting points of view?

\section{Audrey Macklin to James Hathaway, 30 June 2014}

1. I think your point about the tendency to require more than "reasonable chance" to discharge a legal "presumption" is interesting and I need to think about it more. I'm not immediately persuaded that the label "presumption" must require more than a reasonable chance to qualify as a presumption, but you may be on to something as a pragmatic prediction of how "presumption" gets used in practice. What follows from that, I'm not sure, but either way it warrants more thought.

2. My reliance on criminal law is only this: my terminology distinguishes burden of proof from standard of proof, and legal burden from evidentiary burden, in the same way that Canadian law (both criminal and civil) does. And I operate from the proposition accepted in Canadian law that the imposition of an evidentiary burden doesn't change the legal burden of proof. I just want to be sure that when you and I use these terms, we ascribe the same meaning to them. I had the feeling we might be invoking the same terms but giving them different meanings. I certainly agree with you that the actual standard of proof in refugee law is sui generis, or at least distinct from the civil/ criminal standards of proof. As you may know, the legal burden of proof under the Canadian Immigration and Refugee Protection Act for inadmissibility is on the government, yet the standard of proof is notably lower than balance of probabilities ("reasonable grounds to believe") - and it only operates to the disadvantage of non-citizens.

\section{Note \\ 1 James Hathaway and Michelle Foster, The Law of Refugee Status, 2nd ed. (Cambridge: Cambridge University Press, 2014).}

James C. Hathaway is James E. and Sarah A. Degan Professor, and director, Program in Refugee and Asylum Law at the University of Michigan. The author may be contacted at jch@umich.edu.

Audrey Macklin is professor of law and chair in Human Rights at the University of Toronto. The author may be contacted at audrey.macklin@utoronto.ca. 